The Historical Journal, 6o, 2 (2017), pp. $385^{-407}$ (c) Cambridge University Press 2016 This is an Open Access article, distributed under the terms of the Creative Commons Attribution licence (http://creativecommons.org/licenses/by/4.o/), which permits unrestricted re-use, distribution, and reproduction in any medium, provided the original work is properly cited.

doi:10.1017/Soo18246X16000248

\title{
COLLABORATORS, COLLABORATION, AND THE PROBLEMS OF EMPIRE IN NAPOLEONIC ITALY, THE OPPIZZONI AFFAIR, $1805^{-1807 *}$
}

\author{
AMBROGIO A. CAIA N I \\ University of Kent
}

\begin{abstract}
A B S R ACT. The recent bicentennial commemorations of the Napoleonic empire have witnessed a proliferation of new studies. Scholars now possess much more sophisticated conceptual tools than in past decades with which to gauge the problems faced by French imperial administrators throughout Europe. Well-trodden concepts, like centre/periphery or collaboration/resistance, have been reinvigorated by more sophisticated understandings of how rulers and ruled interacted in the early nineteenth century. This article argues that, while much progress has been made in understanding problems of 'resistance', there is more to be said about the other side of the same coin, namely: 'collaboration'. Using the micro/local history of a scandal in Napoleonic Bologna, this article wishes to reaffirm that collaboration was an active agent that shaped, and often shook, the French imperial project. The biggest problem remained that, despite 'good intentions', collaborators sometimes simply did not collaborate with each other. After all, imperial clients were determined to benefit from the experience of empire. The centre was often submerged by local petty squabbles. This article will use a specific micro-history in Bologna to highlight the extent to which Napoleonic empire builders had to thread a fine line between the impracticalities of direct control and the dangers of 'going native'.
\end{abstract}

The importance of the experience of Napoleonic rule for the history of Italy has never been truly in doubt. The region was a vital component of the French empire. ${ }^{1}$ It not only delivered vital resources in terms of revenue and manpower but, more importantly, its control bestowed geo-strategic security on the

School of History, University of Kent, Canterbury, Kent, cT2 7NZ A.A.Caiani@kent.ac.uk

* I would like to thank Prof. Munro Price, Prof. Alan Forrest, Dr Giacomo Macola, and the two anonymous readers for their advice and helpful suggestions with this article.

${ }^{1}$ Alexander Grab, Napoleon and the transformation of Europe (Basingstoke, 2003), pp. 152-75. 
southern fringe of Europe. Despite this apparent dominance, the empire struggled to swallow the peninsula whole and place it under direct control. Italy's landscape was heterogeneous with enormous social, cultural, and geographic diversities. The legacy of the ancien régime, and the manner in which France conquered these territories, made unified administration difficult to establish. Indeed, from 1806 , the population of Italy was divided and administered in no fewer than three separate jurisdictions.

Northern-western Italy was part of metropolitan France, and received its marching orders from Paris. As part of the départements réunis (or annexed departments), Piedmontese, Ligurians, Tuscans, and later the inhabitants of Lazio were placed under the direct control of an increasingly corpulent French nation that had long burst out of its natural frontiers. ${ }^{2}$ The south, after its conquest in 1806, became a satellite kingdom ruled by Napoleonides. Here, the thinly veiled illusion of autonomy was offset by aggressive French domination. ${ }^{3}$ Paris sent bands of French military officers, jurists, spies, policemen, and ministers to drag the old kingdom of Naples into a future that proved distinctly unwelcome to many locals. 4 Essentially, for twothirds of Italians, the experience of French rule was one of subjugation, where the light yoke of ancien régime princes had been exchanged for the heavy and demanding hand of French cultural hegemony.

The situation in the northern and central corner of the peninsula, that is to say the republic/kingdom of Italy, was very different. It has been defined rightly as 'the jewel in the crown of Napoleon's hegemony'.5 Its Lombard and Emilian heartland was more urbanized than the rest of the peninsula, and contained strong native traditions of municipal autonomy mingled together with an illuminist movement that rivalled France's enlightenment. ${ }^{6}$ Napoleon had never forgotten the generally good reception he had received in a large number of Italian cities during his first military campaign. 7 The experience of generating 'sister republics' had given him an important apprenticeship in the arts of

${ }^{2}$ Michael Broers, Napoleonic imperialism and the Savoyard monarchy, I773-I82 I: state building in Piedmont (New York, NY, 1997); and see also idem, The Napoleonic empire in Italy, I 796-I8I4: cultural imperialism in a European context (New York, NY, 2005).

3 John Davis, Naples and Napoleon: southern Italy and the European revolutions, I780-I860 (Oxford, 2006); Albert Espitalier, Napoleon and King Murat (Tyne and Wear, 1912); and Michel Lacour-Gayet, Joachim et Caroline Murat (Paris, 1996), pp. 161-235.

4 Milton Finley, The most monstrous of wars: the Napoleonic guerrilla war in southern Italy, I8o6I ${ }_{\text {I I }}$ (Columbia, SC, 1994).

5 Michael Broers, 'A clash of enlightenments: judicial reform in the Napoleonic republic and kingdom of Italy', in Michael Broers, The Napoleonic Mediterranean (London, 2016).

6 Carlo Zaghi, L'Italia di Napoleone (Turin, 1989); Domenico Sella and Carlo Capra, Il ducato di Milano dal 1535 al 1796 (Turin, 1984), esp. pp. 557-617; and Franco Venturi, Italy and the Enlightenment (New York, NY, 1972), esp. chs. 6, 7, and 10.

7 For the most recent descriptions, see Michael Broers, Napoleon: soldier of destiny (London, 2014), pp. 126-33; and Philip Dwyer, Napoleon: the path to power, I769-I799 (London, 2007), pp. 219-22. 
government and politics. Himself the descendant of Ligurian adventurers, the emperor had mixed feelings when it came to the land of his ancestors. ${ }^{8}$

Italy remained both familiar, and infuriatingly remote, in a manner that no other part of the empire ever could parallel. Germans, Poles, Spaniards, and Croatians were authentically 'other' whereas Milanese and Bolognese elites were troublesome cousins. This is why, to an extent unknown anywhere else, in the empire Lombards and Emilians were given positions of authority as officers, ministers, prefects, and prelates. The efficient, hardworking Eugène de Beauharnais, viceroy of these lands, was told by his imperious stepfather to listen to his Italian ministers, especially the formidable Prina. ${ }^{9}$ In contrast, Louis Bonaparte in Holland was reminded constantly he was a French prince and not a Dutch monarch. ${ }^{10}$ The republic and successor kingdom of Italy were allowed flexibilities that did not exist elsewhere in the empire.

For instance, the system of voting was different from that of France. It organized Italian notables into three electoral colleges divided to bestow representation on landowners, merchants, and the intelligentsia. ${ }^{11}$ The 1803 Italian Concordat enshrined the somewhat meaningless concession to the church that Catholicism here, unlike in France, was a state religion. ${ }^{12}$ Equally, after much quibbling, a separate (and cosmetically altered) code of criminal procedure was bestowed on this province in $1807 .{ }^{13}$ Unlike for other satellite realms, the Italian first minister Antonio Aldini and the kingdom's foreign minister Ferdinando Marescalchi resided in Paris. ${ }^{14}$ This was not a sign of subjugation but highlighted that the emperor wished to have Italian opinion represented in his capital and allowed these two ministers to lobby on behalf of their imperial constituency. In the capital, they had unparalleled access to elite French society and the imperial court. It should be noted that these autonomies were 'ornamental' rather than fundamental in nature. However, they do illustrate that in Milan, more than anywhere else, the sensibilities of local elites were

${ }^{8}$ Michel Vergé-Franceschini, Napoléon: une enfance corse (Paris, 2009), pp. 13-28, 193-221; Alain Pillepich, Milan, capitale napoléonienne, I800-I8I4 (Paris, 2001), pp. 61-73.

9 Fondation Napoléon, Napoléon Bonaparte: correspondance générale (15 vols., Paris, 2004-18), No. 10224, Milan 18 prairial an XIII 5 juin 1805 , v, pp. 386-8 (henceforth: Napoléon Bonaparte, Correspondance générale); Albert Du Casse, Mémoires et correspondance politique et militaire du Prince Eugène (10 vols., Paris, 1858-6o), I, pp. 227-31; and Silivo Pellini, Giuseppe Prina: ministro delle finanze del regno italico (Milan, 19oo).

${ }^{10}$ Napoléon Bonaparte, Correspondance generale, No. 15008, Osterode 30 mars 1807, VII, pp. 507-8; and Annie Jourdan, ed. Louis Bonaparte, roi de Hollande (Paris, 2010), pp. 417-33.

${ }_{11}$ Zaghi, L'Italia di Napoleone, pp. 2-16; the constitution of Bayonne seems to have been modelled on Italian electoral practices, cf. Pierre Conard, La constitution de Bayonne, I 8o8: essai d'édition critique (Paris, 1910), pp. 117-19.

12 Daniele Arru, Il Concordato italiano del I 803 (Milan, 2003), pp. 39-47.

13 Melchiorre Roberti, Milano capitale napoleonica: la formazione di uno stato moderno, I796I8I4 (3 vols., Milan, 1947), II, pp. 95-110.

${ }^{14}$ Antonio Zanolini, Antonio Aldini ed $i$ suoi tempi: narrazione storica con documenti inediti o poco noti (2 vols., Florence, 1867); and Teresa Muzzi, Vita di Ferdinando Marescalchi, patrizio bolognese (Rome, 1932). 
taken seriously and attempts were made, at the very least, to spare their feelings. This less piercing version of French imperial rule is something that scholars have tended to overlook.

The latest interpretations from the 'new Napoleonic history' have argued that the different cultural, administrative, and political reforms undertaken in Italy were akin to a clash of civilizations. ${ }^{15}$ Michael Broers has borrowed the concepts of 'cultural imperialism' and 'orientalism' from the literary critic Edward Said to highlight the intolerance of the French empire builders toward their subject peoples. ${ }^{16}$ This highly influential reinterpretation remains admirable in its goal of placing the Napoleonic episode in its broadest possible comparative context and analysing it with a number of well-chosen theoretical tools from neighbouring disciplines. ${ }^{17}$ These studies, in particular, have underscored how the different ancien régimes and political geographies, scattered throughout Europe, left in the wake of their destruction a mixed inheritance. This determined both the nature and limits of Napoleonic rule outside of metropolitan France. ${ }^{18}$

Despite these new studies, scholars of Napoleonic Europe have tended to neglect theoretical perspectives from imperial history on the thorny issue of native elite 'collaboration'. ${ }^{19}$ In a now classic article from 1972, Ronald Robinson presented a theoretical outline, whereby native collaborators on the periphery were not mere pawns, but shaped the dynamics of empire. ${ }^{20}$ This insight certainly speaks to the Napoleonic context, as the French empire was exceedingly keen to promote partnerships with indigenous elites. In doing this, it faced several headaches similar to those identified by Frederick

15 Michael Broers, 'Napoleon, Charlemagne, and Lotharingia: acculturation and the boundaries of Napoleonic Europe', Historical Journal, 44 (2001), pp. 135-54; Stuart Woolf, 'French civilization and ethnicity in the Napoleonic empire', Past and Present, 124 (1989), pp. 96-120; and for the most recent survey, Michael Broers, 'Napoleon, his empire, our Europe and the new Napoleonic history', in Michael Broers, Peter Hicks, and Augustín Guimerá, eds., The Napoleonic empire and the new European political culture (Basingstoke, 2012), pp. 1-17; and Michael Broers, Steven Englund, Michael Rowe, and Annie Jourdan, 'Napoléon et l'Europe: le point de vue Anglo-Américan', Annales Historiques de la Révolution Française, 354 (2008), pp. 131-53.

${ }^{16}$ Michael Broers, 'Cultural imperialism in a European context? Political culture and cultural politics in Napoleonic Italy', Past and Present, 170 (2001), pp. 152-80.

17 Steven Englund, 'Monstre sacré: the question of cultural imperialism and the Napoleonic empire', Historical Journal, $5^{1}$ (2008), pp. $215^{-} 5^{\circ}$.

18 Broers, Europe under Napoleon, I799- I 8 I5 (London, 1996), pp. 6-14 and ch. 3; and idem, 'The myth and reality of Italian regionalism: a historical geography of Napoleonic Italy, 18011814', American Historical Review, 108 (2003), pp. 688-7o9.

${ }^{19}$ Jane Burbank and Frederick Cooper, Empires in world history: power and the politics of difference (Princeton, NJ, 2010), pp. 219-5o.

${ }^{20}$ Ronald Robinson, 'Non-European foundations of European imperialism: sketch for a theory of collaboration', in Roger Owen and Bob Sutcliffe, eds., Studies in the theory of imperialism (London, 1972), pp. 117-42, esp. p. 121 ; this view remains influential with a number of recent studies of empire; see John Darwin, Unfinished empire and the global expansion of Britain (London, 2012), pp. 11-12; and more idiosyncratically Gregory A. Barton, Informal empire and the rise of one world culture (Basingstoke, 2014). 
Cooper. ${ }^{21}$ There was an inherent danger that by assimilating northern Italians excessively into the imperial hierarchy they could de-rail the Napoleonic state's 'progressive crusade' for their own ends. ${ }^{22}$ Collaboration partnerships were never supposed to be equal relationships, and delegating too much authority to Milanese and Bolognese officials was fraught with risks. As Alice Conklin has shown elsewhere, collaboration was hardly fixed in nature and was repackaged as imperial priorities mutated. ${ }^{23}$ The fluctuating position and divisions among indigenous supporters, within the French Imperium, gave raise to several unexpected problems.

Michael Rowe's study of the Napoleonic Rhineland and a number of areaspecific studies on collaboration have done much to counteract a past tendency to dismiss the German, Italian, and Dutch 'Jacobins' who greeted favourably France's revolutionary, and later Napoleon's conquering, armies. ${ }^{24}$ T. C. W. Blanning, paraphrasing Churchill, summed this up: 'rarely in the field of historical scholarship has so much attention been lavished by so many on so few'. ${ }^{25}$ $\mathrm{He}$ is correct that the Andreas Hofmanns, Pieter Vreedes, or the unhinged Antonio Ranzas of this world were few and far between in number. Yet it could be argued that to restrict collaborators to a fervently committed minority of revolutionary or Napoleonic fanatics reduces and distorts the significance of this complex social grouping. The non-French Napoleonic collaborator was propelled by a mixture of motivations and complete ideological commitment was decidedly rare.

Many showed great reluctance when it came to imperial service and assisted the empire as opportunistic, often unenthusiastic, converts who wanted to reap the benefits that imperial rule brought in terms of investment, law, order, and patronage. Among their number were ancien régime public servants, lawyers/

21 Frederick Cooper and Laura Stole, eds., Tensions of empire: colonial culture in a bourgeois world (Los Angeles, CA, 1996), p. 7 .

${ }^{22}$ Frederick Cooper, Colonialism in question: theory, knowledge, history (Los Angeles, CA, 2005), p. 154; a view he later refined, stating that all empires had 'to find a balance between the poles of incorporation (the empire's claim that different subjects belonged within the empire) and differentiation (the empire's claim that different subjects should be governed differently) was a matter of dispute and shifting strategies'. Indeed, the Napoleonic empire was equally caught in the maelstrom created by these centripetal and centrifugal forces. See Cooper, Colonialism in question, p. 154 .

23 Alice L. Conklin, A mission to civilize: the republican idea of empire in France and West Africa, I895-I930 (Stanford, CA, 1997), pp. 6-8 and $15^{-20 .}$

${ }_{24}$ Michael Rowe, From Reich to state: the Rhineland in the revolutionary age, I780-I 830 (Cambridge, 2003), pp. 53-83 and ch. 4; Michael Rowe, ed., Collaboration and resistance in Napoleonic Europe: state-formation in an age of upheaval, c. I80o-I8I5 (Basingstoke, 2003), pp. 1-18; Umberto Caldora, Calabria napoleonica, I806-I8I5 (Naples, 196o); Miguel Artola, Los Afrancesados (Madrid, 1953); and Jean-Marc Lafon, L'Andalousie et Napoléon: contre-insurrec-

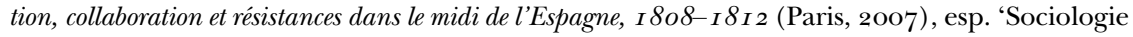
de la collaboration andalouse'.

${ }_{25}$ Timothy Blanning, Joseph II (London, 1994), p. 204; and his earlier 'German Jacobins and the French Revolution', Historical Journal, 23 (1980), pp. 985 $5^{-1002 .}$ 
togati, absolutist reformers, and magnates who recognized in the Napoleonic regime many of the features and values that they had supported under the previous administration. For instance, Milanese patricians such as Francesco Melzi d'Eril and Carlo Verri (brother of the more famous Pietro) had matured under the reforming culture of Joseph II's enlightened absolutism and they found affinities with the new regime. ${ }^{26}$ They served not out of a personal loyalty to Napoleon, but out of a long-held sense of devotion to the reforming state. These men were extremely different in both outlook and behaviour from the Giacobini who had supported the French since 1796.

The relationship between the imperial centre and its more enthusiastic Italian supporters was characterized by significant 'mistranslation'. The emperor's directives and policies were at times genuinely misunderstood by Italians who had not experienced the turmoil of the 179os in France. More often, former Jacobins deliberately distorted orders from the centre, to suit individual and local circumstances. For example, many Italian urban officials, especially disappointed Jacobins/patriots, continued to hope against all odds that French hegemony might restore some of the autonomies and privileges that their municipality had lost during the settecento riformatore. To maintain indigenous support, the empire fed and manipulated such misunderstandings. Throughout this period, imperial patronage vacillated between Melzi's Josephists and former Giacobini.

For their part, local collaborators hoped that they could redirect the resources and prestige of the centre to the benefit of their periphery. They hoped that interaction with Napoleon's empire would not just bring advantages, wealth, and promotion but also settle old scores. For former Giacobini, using the power of the empire to surpass and outperform rivals was perhaps the most enticing feature of these collaborative networks. They hoped that the empire would bring promotions and expected, often in vain, that it would resolve long-standing disputes that the ancien régime had singularly failed to address in their favour.

Essentially, ancien régime identities, local interests, and Napoleonic reforms made collaboration a volatile compound. ${ }^{27}$ Persuading such diverse social groups to work together could never be defined through a precise formula. Partnership with indigenous elites was a delicate set of compromises, which even the smallest alteration could unsettle. Simplistically speaking, new administrative elites and old aristocracies, at times, found themselves at odds with their

${ }^{26}$ See Francesco Melzi d'Eril [great grandson], Francesco Melzi d'Eril, I 753-I8I 6: milanese scomodo e grande uomo di stato, visto da un lontano pronipote (Florence, 2000), esp. 227-88; and Nino del Bianco, Francesco Melzi d'Eril: la grande occasione perduta, gli albori dell'indipendenza nell'italia napoleonica (Milan, 2002), passim.

27 Broers, Europe under Napoleon, I799-I 8 I5, pp. 125-43; Gabriel Lovett, Napoleon and the birth of modern Spain (2 vols., New York, NY, 1965), II, pp. 554-6o9; and John Dunne, 'Power on the periphery: elite-state relations in the Napoleonic empire', in Alan Forrest and Philip Dwyer, eds., Napoleon and his empire (Basingstoke, 2007), pp. 61-78. 
French imperial overlords, while at other junctures, they were content to benefit from reforms and new institutions. However, such a picture is too neat as it implies that collaborators shared the same interests and motivations. As will become apparent, they were far from being socially harmonious. The twin policies of amalgame and ralliement hid from view the centre's difficulties in promoting networks of amity. ${ }^{28}$ Napoleonic imperialism, especially in the satellite kingdoms, was a somewhat floundering attempt to create what David Cannadine elsewhere has called Ornamentalism. ${ }^{29}$ The empire could not rely exclusively on coercion. The emperor and his administrators fostered, as much as possible, a shared sense of affinity with indigenous elites. ${ }^{30}$ The satellite kingdoms made the French empire poly-nuclear rather than absolutely centripetal in nature. $3^{1}$

Many methodologies have been applied to the study of Napoleonic collaboration. These include prosopography, anthropology, and archaeology. These are all tools that have profited scholars of nineteenth-century European imperialism and have shown every sign of being equally useful to historians of Napoleonic Europe. $3^{2}$ The most difficult area remains 'intermediate history' or the attempt to link 'micro' or local events in the periphery with the 'macro' context of empire. From this perspective, the increasingly forgotten art of micro-history could make an original contribution to the issue of collaboration.

Famously, Carlo Ginzburg, followed by many others, in the 1980 os pioneered a new approach to history which focused on archival cases-studies that were both individual and local.33 At its heart, 'micro-history' examines trials, local conflicts, and extraordinary incidents. From very specific cases, this mode of historical analysis draws out broader social and cultural trends. It seeks to gauge what such extraordinary events reveal about the norms and power structures of the past societies in which they occurred. Francesca Trivellato has argued recently that even in an age of global history the micro-historical is

28 S. J. Woolf, Napoleon's integration of Europe (London, 1991), pp. 109-10.

29 David Cannadine, Ornamentalism: how the British saw their empire (Oxford, 2001), ch. 7 . Invented traditions such as the ordre de la réunion and the proposed ordre des trois toisons highlighted that the 'European other' was welcomed into the imperial fold if it shed unhealthy past allegiances and embraced the new. Jean-Luc Stalins, Ordre impérial de la réunion (Paris, 1958); Emanuele Pigni, L'ordine della corona di ferro e le altre ricompense concesse da Napoleone I nel regno italico (Milan, 2014); and Jean Joseph Taurignac, L'ordre impérial des trois toisons d'or (Paris, 1907).

$3^{\circ}$ Jean and Marie-José Tulard, Napoléon et quarante millions de sujets: la centralisation et le premier empire (Paris, 2014).

$3^{1}$ Owen Connelly, Napoleon's satellite kingdoms: managing conquered peoples (Malabar, 1990).

$3^{2}$ Broers, 'Cultural imperialism in a European context?', pp. 152-80.

33 Carlo Ginzburg, The cheese and the worms: the cosmos of a sixteenth-century miller (Baltimore, MD, 2013). Recently, this approach has been question; see Jo Guldi and David Armitage, The history manifesto (Cambridge, 2014), esp. pp. 38-6o. 
invaluable in unearthing connections between individuals and transnational networks. 34 Micro-history by its very nature deals with events that are exceptional. This is its great strength as a heuristic device. It is only when the political, social, and cultural norms of society are thrown into flux that mechanisms of power emerge from the shadows and become visible. Consequently, trials, scandals, gossip, and other bizarre events have immense revelatory potential.

One suspects that micro-history as an approach has much to recommend it to the Napoleonic scholar. There were no shortages of incidents, scandals, and affairs during these momentous fifteen years. It is this author's very good fortune to have unearthed one such incident that sheds new light on the phenomenon of collaboration in Napoleonic Italy. The Oppizzoni affair erupted onto the political scene in 1806 and caused a huge headache for the imperial administrators in Napoleonic Italy. Though mentioned en passant in the work of Thiers, Beseghi, Antonelli, and Varni, no historian has examined this episode in detail.35 This is remarkable considering that the trial records comprise over 2, ooo manuscript folios (luckily they escaped the bombing of Milan's state archives in 1944). $3^{6}$ Excitingly, the papers were still sealed when I first consulted them. Equally, Cardinal Oppizzoni's voluminous private papers are still housed today in Bologna's archiepiscopal archives. 37 Therefore, the specific micro-history discussed in the second half of this article has the benefit of being remarkably well documented, and takes the reader to the very heart of the problems that faced Napoleonic collaboration networks.

\section{I}

Bologna, like so many Italian cities, has a complex local history. As the site of the first university in Europe, the relationship between 'town and gown' would influence deeply the city's urban development during the medieval period. $3^{8}$ Subsequently, the defeat of the Bentivoglio family and the conquest of the city by Julius II meant that the church would recreate the political, cultural,

34 Francesca Trivellato, 'Is there a future for Italian microhistory in the age of global history?', Californian Italian Studies, 2 (201 1), pp. 1-24.

35 Adolphe Thiers, Histoire du consulat et de l'empire: faisant suite à l'histoire de revolution française (20 vols., Paris, 1845-62), XII, p. 61; Umberto Beseghi, I tredici cardinali Neri (Florence, 1944), pp. 82-97; Livio Antonelli, I prefetti dell'Italia napoleonica (Bologna, 1983), pp. 274-9; and Angelo Varni, Bologna napoleonica: potere e società dalla Repubblica cisalpina al regno d'Italia (Bologna, 1973), pp. 253-7.

$3^{6}$ Archivio di Stato di Milano (ASMi), Atti di Governo, Giustizia Punitiva PM 59, Processo detto di Bologna.

37 Archivio Arcivescovile di Bologna (AAB), Fondo Oppizzoni, Cartella 8; and Mario Fanti, 'Documentazione di età napoleonica nell'Archivio generale arcivescovile di Bologna', in Angelo Varni, ed., I 'Giacobini’ nelle legazioni: gli anni napoleonici a Bologna e Ravenna (3 vols., Bologna, 1996), II, pp. 273-83.

$3^{8}$ Luigi Simeoni and Albano Sorbelli, Storia della Università di Bologna ( 2 vols., Bologna, 1944-7), II, pp. $7^{-25}$. 
and economic topography of the city in its own image. 39 By 1796 , the archdiocese comprised 6 cathedral chapters, 404 parishes (53 intra-muros), and no fewer than 25 monasteries. Comparatively, in Bologna the ratio of religious to lay inhabitants was 1 to 17 whereas in Milan it was 1 to $60.4^{\circ}$

The Sistine decrees of 1559 established a senate and other political institutions to administer the citizenry. ${ }^{4}$ This charter established the basic constitutional framework under which the municipality was governed for almost three centuries. The papal legations of Bologna, Ferrara, and Ravenna, not to mention their fertile countryside, were among the most economically significant provinces of the patrimony of St Peter. The papal legates, despite their bad nineteenth-century reputation, ruled these provinces with a light touch and local autonomies, especially in the realm of taxation, were respected if hardly relished by St Peter's successors.

Traditional and popular histories of the city characterize the eighteenth century as a time of stagnation. Such a vision is not entirely fair given that even the papal states could hardly remain immune from the enlightened reformism that was taking place in Lombardy, Tuscany, and Modena. ${ }^{2}$ Under Benedict XIV and Pius VI, significant, though slow, judicial, economic, and fiscal reforms were taking place. 43 Certainly, Bologna was not a place of opportunity for young men and mid-grade administrative personnel. Political power was shared between a cardinal legate and a senate composed of fifty aristocrats. This elite constituted a tiny minority in a city of 63 ,ooo inhabitants (half the size of Milan).44 The senatorial oligarchy, supported by private policemen/thugs, known as sbirri, did their best to resist central authority's incursions into the municipal administration. Attempts by the criminal court, the Tribunale del Torrone, to pursue modernized rather than patrimonial forms of justice met with violence. Indeed, a number of reformist magistrates were dispatched with harquebus shots while conducting criminal prosecutions. 45

The arrival of the French in 1796 must have built up expectations amongst the educated bureaucratic milieu of this city. On his arrival, General

39 Aldo Berselli and Angelo Varni, eds., Storia di Bologna: Bologna in età contemporanea, IV (Bologna, 2010), pp. 1-4.

$4^{\circ}$ Ivana Pederzani, Un ministero per il culto: Giovanni Bovara e la riforma della chiesa in età napoleonica (Milan, 2002), pp. 98-105; Ugo Da Como, Atti delle assemblee costituzionali italiane (Rome, 1968), p. 599; Filiberto Agostini, La riforma napoleonica della chiesa nella repubblica e nel regno d'Italia, I802-I8I4 (Vicenza, 1990), pp. 114-18.

$4^{1}$ Giancarlo Angelozzi and Cesarina Casanova, La giustizia criminale in una città di antico regime: il tribunale del torrone di Bologna secc. XVI-XVII (Bologna, 20o8), pp. 21-41.

$4^{2}$ M.S. Anderson, 'The Italian reformers', in Derek Beales and Hamish Scott, eds., Enlightened absolutism: reform and reformers in later eighteenth-century Europe (London, 1990), pp. $55^{-74}$.

43 Venturi, Italy and the Enlightenment, pp. 225-64.

44 Zaghi, L'Italia di Napoleone, pp. 82-4 and 104-5.

45 Giancarlo Angelozzi and Cesarina Casanova, La giustizia criminale a Bologna nel XVIII secolo $e$ le riforme di Benedetto XIV (Bologna, 2010), passim. 
Bonaparte hinted that Bologna might expect a restoration of the medieval Libertas it had lost in $\mathbf{1}_{5}$ o6. The first modern Italian constitution was proclaimed in the Cathedral of St Petronius. Briefly, from 26 April to 27 July 1 797, the city was the capital of the short-lived Cispadane Republic. $4^{6}$ Many students, lawyers, and minor aristocrats greeted the French enthusiastically as they saw opportunities for advancement and adventure in the new republican regime. The Circolo Costituzionale of Bologna was a decided breeding ground for future Napoleonic collaborators. 47 The subsequent incorporation of these lands into the larger Cisalpine Republic was something that deeply irked Bolognese sensibility and ignited a rivalry with Milanese elites. Equally, the peasantry of the surrounding countryside and even the artisanal workers of the city showed themselves little enthused by their new masters, who quickly made significant demands in terms of taxation and requisitions.

The re-conquest of Bologna in 1800 , and the subsequent 1802 revolts of the Bolognese, were a turbulent period for the city and revealed that its loyalty could not be taken for granted. $4^{8}$ Yet, by the time Napoleon transformed his Italian client republic into his first satellite kingdom in 1805 , much had been done to promote harmony in the department of the Reno, of which Bologna was the administrative centre. The city was made the institutional seat of the University, National Institute, Academy of Fine Arts, and Collegio dei Dotti.49 With the incorporation of the Venetian departments into the client state, in years following the battle of Austerlitz, Bologna now found itself on a central artery that linked Milan and Venice to the rest of the triskelion-shaped northern Italian kingdom. $5^{\circ}$ With the forced retirement of Melzi in $1805,5^{1}$ Bolognese elites now occupied the pinnacle of society in the new kingdom. The secretaryship of state, the Italian Ministry of Foreign Affairs, the Italian grandmastership of the horse, and the position of the cardinal archbishop of Milan were all offices held by Emilian collaborators of Napoleon..$^{2}$ Yet this appearance of success and growing importance hid from sight lingering jealousy and resentments.

It was some weeks after the battle of Austerlitz that events of the micro- and local history in question began. January 1806 was a particularly busy period for the surgeon Gaetano Gozzi. He was charged officially, by the prefectural police, with ministering medical treatments to the workers of several tolerated brothels

$4^{6}$ Berselli and Varni, eds., Storia di Bologna, pp. 8-2o.

47 Umberto Marcelli, Il Gran circolo costituzionale e il Genio democratico, I 797-I 798 (3 vols., Bologna, 1986).

$4^{8}$ Varni, Bologna napoleonica, pp. $111-44$.

49 Zaghi, L'Italia di Napoleone, pp. $113^{-14}$ and $211-17$.

$5^{\circ}$ Emanuele Pagano, Enti locali e stato in Italia sotto Napoleone: repubblica e regno d'Italia, I $802-$

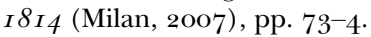

$5^{1}$ Zaghi, L'Italia di Napoleone, pp. 49-52.

$5^{2}$ Ibid. 
of Bologna.53 Following the legacy of enlightened absolutism, the French empire had sought to regulate and limit the health hazards that followed in prostitution's wake with unprecedented vigour.54 The therapies designed to cure venereal disease in the early nineteenth century were decidedly unpleasant, requiring the administration of mercury to the affected areas.55 On this dark night, Gozzi was summoned by a mistress of a brothel called Maria Cenasi (also lovingly known as the 'Diavoletta' or little-she-devil). One of her girls, the fourteen-year-old Anna Naldi, a recent recruit to her profession, had contracted gonorrhoea and required medical attention. The surgeon Gozzi obedient to his medical vocation started treating his patient. As the girl cried in agony her mind must have strayed to the potential culprits who had bestowed this horrid affliction.

As the pain became unbearable, she suddenly screamed in a loud voice, 'damn those red socks and that crimson skull cap'. Initially, Gozzi did not think to enquire as to her meaning and merely suspected she was euphemizing. But, as proceedings continued, he realized that her words were intended to allude to the identity of a specific individual. The surgeon, curious as any man in his position would be, asked the girl to explain herself. She answered nonchalantly 'I mean the boss of the city's priests.' $5^{6}$ Within days, rumours started to circulate throughout the city that Cardinal Oppizzoni, the archbishop of Bologna, had 'deflowered' an adolescent girl and induced her into a life of prostitution.

Oppizzoni was one of Napoleon's most favoured prelates and an ecclesiastical high-flyer. He had possessed the enviable ability, aided by his aristocratic birth as the son of a Milanese count, to be not only in the right place at the right time but, more importantly, he had proved remarkably versatile when it came to politics. Through his Greppi, Trivulzio, and Barbiano di Belgiojoso cousins he was related to many of the enlightened aristocrats who had sought to push forward Joseph II's programme of reform. 57 As archpriest of the Duomo (Cathedral) of Milan he had welcomed the French invaders. During the negotiations at the 'Comices de Lyon', which created the Italian Republic (1802-4), he had been the archbishop of Milan Cardinal Visconti's deputy. The sudden death

53 Sara Accorsi and Anna Natali, Salariate dell'amore: storie e faccendi meretrici nell'Ottocento bolognese (Bologna, 2010), pp. $111-5^{\mathrm{O}}$; and Maurizio Garuti and Anna Natali, Amori illeciti nella legazione pontificia di Bologna (Bologna, 2007), pp. 159-83.

54 ASMi, Atti di Governo, Giustizia Punitiva PM 59, Atti Originali, Doc. 14, Adi 16 marzo 1806 , Witness statement of Gaetano Gozzi.

55 Joan Sherwood, Infection of the innocents: wet nurses, infants, and syphilis in France, I $780-1900$ (Montreal, 2010), pp. 12-23.

$5^{6}$ ASMi, Atti di Governo, Giustizia Punitiva PM 59, Atti Originali, Doc. 14, Adi 16 marzo 18o6, Witness statement of Gaetano Gozzi, fo. 1.

57 Danilo Marrara, Ceti dirigenti municipali in Italia e in Europa in età moderna e contemporanea (Pisa, 2005), p. 31; Anon., Applausi poetici a S. E.za. Rev.ma. il Sig Carlo Oppizzoni in occasione del suo ritorno dalla Francia (Bologna, 1814); M. Petrocchi, La restaurazione romana (Florence, 1943); Ugo Da Como, I comizi nazionali a Lione (3 vols., Rome, 1934-40). 
of the latter during the banquet, held in honour of Italian deputies, meant that the young archpriest was thrust into the limelight and took over from his dead patron.

He showed himself a reliable and pliant ecclesiastical client of France. He approved the repressive organic laws intended to supervise the activities of the church (which Rome subsequently disavowed) and voted for Napoleon to become president of the Italian Republic. Two years later, he was a senior member of the team which, under Cardinal Caprara's stewardship, negotiated the Italian Concordat of $1803 \cdot 5^{8}$ His accommodating stance before his French masters paid dividends. In 1802, he was made archbishop of Bologna and in 1804 , received the cardinal's galero, which, at the age of thirty-five, was an impressive achievement. 59 He was also made a member of the corpo legislativo in the same year, which effectively made him a member of Napoleon's Italian parliament. ${ }^{60}$ Such eminent ecclesiastical friends were literally a godsend to the Napoleonic regime. Oppizzoni's adherence to the kingdom of Italy had little ideological content and mainly sought to promote harmonious relations between church and state.

This crucial clerical collaborator was the man whom the young Anna Naldi accused of being the source of her venereal affliction. The surgeon, Gozzi, decided to bring the matter to the attention of the city's police. These officials in turn made very far from discreet enquiries and gave the impression that they were preparing a prosecution against this prince of the church. Subsequent trial proceedings highlight how outbursts of laughter and loud jocular discussions in their headquarters alerted many passers-by that something unusual was afoot. ${ }^{61}$ The records demonstrate that in an age when newspapers were heavily censored, word of mouth and rumour proved very effective media for the dissemination of, admittedly, unreliable information. Thanks to the city's many taverns, especially the seediest den, the hostelry of the Three Hunchbacks, the cardinal's sexual proclivities were debated keenly. ${ }^{62}$ Bizarrely, no one questioned why the prelate had chosen a rather downmarket prostitute in fragile health rather selecting a healthy, witty, and high-

$5^{8}$ Arru, Concordato Italiano del 1803 , pp. $40-4$ and 77 .

59 He would hold both of these positions until his death in $185^{1}$, and would quell no fewer than two revolutions in his diocese. G. Natali, Il cardinale Oppizzoni legato a latere per le quattro legazioni dal 2 I marzo al 3 I maggio I 82 I (Bologna, 1931).

6o Roberti, Milano capitale napoleonica, I, p. 267.

61 ASMi, Atti di Governo, Giustizia Punitiva PM 59, Atti Originali, Doc. 2, 2 marzo 1806 , Witness statement of Giovanni Francesco Da Vita, fos. 1-3. This witness first heard rumours of the Oppizzoni affair in the public house (Bottega) run by Tommaso Pirotti. He names twelve individuals who discussed this case and describes how it spread by word of mouth to the nearby Caffè degli Stelloni and then further afield; and Doc. 11, 14 marzo 1806, Witness statement of Gaetano Zurla, fos. 1-4. This testimony confirms that police laughter and jocularity over the affair alerted local residents that something was afoot.

${ }_{62}$ ASMi, Atti di Governo, Giustizia Punitiva PM 59, Atti Originali, Doc. 1 2, 15 marzo 18o6, Witness statement of Tommaso Mezzopiede Parroco di S Benedetto, fo. 1. 
maintenance courtesan instead. ${ }^{63}$ Almost immediately, songs, ballads, and modified versions of the psalms describing the cardinal's over-zealous care of the souls entrusted to him were in circulation. Oppizzoni realized that the situation was untenable.

At nightfall, the cardinal packed his bags and headed for the imperial palace at Monza. The viceroy, Eugène de Beauharnais, was more than a little surprised to be roused by the cardinal in a state of great nervous excitement. He stated that he had been slandered, and refused to return to Bologna until his name was cleared and his innocence vindicated. Eugène promised every support but, true to his step-father's instructions, contacted Paris. The emperor's gut response showed that he had a rather minimalist approach when it came to child protection:

I am surprised and angry about what has happened to the archbishop of Bologna. Write to the prefect, if this affair is still kicking up trouble, have the girl and her procuress locked up in Bicêtre. Translate this term into a Milanese equivalent. Tell him that I honour the Cardinal Oppizzoni and that I have no intention that a go-between and a girl will compromise such a respectable person, even if in truth he may have his weaknesses. There is no question of this. ${ }^{64}$

The emperor's reference to Bicêtre (a borstal in Paris for young offenders) highlights he was thinking in decidedly French terms. He wanted to defuse the situation with a light custodial punishment for Anna Naldi. This is a good example of 'mistranslation', where the centre issued commands that were culturally specific, and fundamentally misunderstood the Italian context. A light touch à la française in this affair was not going to resolve the issue. Three weeks later the situation showed absolutely no sign of abating. Napoleon wrote more than a little irked that:

If Cardinal Oppizzoni is innocent, the injury visited on him demands vengeance; if instead he is guilty the circumstance is no less serious. Talk on my behalf to the cardinal; make him aware of my opinion in this matter, if the allegation is true, I still hold the administration of Bologna guilty [of being indiscreet], and if the facts are false, exemplary punishment must be meted out. If, in fact the accusation is not true, order the prostitute, her procuress and the man who impersonated the cardinal to be arrested, and give great éclat to this infamous affair; but you must be absolutely sure of the facts. ${ }^{6}$

One suspects that Napoleon, with his rather low estimation of human nature, thought that there was no smoke without a fire. The emperor wanted a cover up only if the facts went against the cardinal. It was inconceivable that a

63 Cf. Erica-Marie Benabou, La prostitution et la police des moeurs au XVIIIe siècle (Paris, 1987); and Nina Kushner, Erotic exchanges: the world of elite prostituion in eighteenth-centry Paris (London, $2013)$.

64 Napoléon Bonaparte, Correspondance générale, No. 11616, 7 mars 1806, vi, p. 194.

65 Ibid., No. 11788,27 mars 1806 , vi, pp. 276-7. 
fourteen-year-old prostitute could compromise a man perched at the summit of the Catholic hierarchy. After all, the emperor had stated that 'bishops were merely prefects with red socks', that is, they like bureaucrats were state officials. In this respect, he showed a fundamental misunderstanding of religion, typical of post-revolutionary French mind-sets. Catholic religious issues, especially those relating to clergymen, could not be tackled solely through secular means.

The cardinal, after receiving further reassurances by the viceroy, became decidedly over-confident. He wrote to Rome an emotional letter asking what he should do if those who had sullied his name were condemned to death. The cardinal secretary of state Consalvi ${ }^{66}$ replied in the following, chilling, manner:

If this is the case [that those guilty of slandering you are condemned to execution] your eminence will behave in the conciliatory manner of the good shepherd and will make overtures that the accused be saved from the death penalty. If his pastoral offices fail to be effective his eminence will have played a role above reproach and his conduct, on the contrary, will be considered praiseworthy by all. ${ }^{67}$

There was something of the surreal in these daydreams shared between clergymen, who ignored how French penal legislation since the 1790 s tended towards leniency in cases of injurious speech, calumny, libel, and slander. ${ }^{68}$ Most damaging of all, the cardinal was handicapped by the fact that Rome had never recognized officially the state's criminal jurisdiction over clergymen. Therefore, Oppizzoni refused to have any direct role in his own trial. This meant that the judicial authorities of the Italian kingdom were expected to conduct a prosecution for slander when nobody officially would appear in court claiming to have been injured or libelled.

Meanwhile, elsewhere, events were taking an unexpected turn. Late on the evening of 28 February 1806 , the sentries at the city gates of Bologna did not anticipate further activity. This largely explains why they were taken by surprise when an official government carriage carrying Giovanni Villa, the undersecretary of state for police, arrived in the city. ${ }^{69}$ This official's first port of call was the barracks of the local gendarmerie (military police). Here, armed with a ministerial letter conferring unlimited powers to execute his secret mission, he ordered that Colonel Zanetti place at his immediate disposal two armed gendarmes in civilian dress.

66 John Martin Robinson, Cardinal Consalvi, I757-I824 (London, 1987); and Ercole Cardinal Consalvi, Mémoires du Cardinal Consalvi (2 vols., Paris, 1866), I, pp. 458-6o2.

67 AAB, Fondo Oppizzoni, Cartella 8, Fasc. 1, Doc. 10, 29 aprile 1806, fos. 1-3.

68 See $\$ 11$, 'Calomnies, injures, révélations des secrets', in Code pénal (Paris, 1810), pp. 81-4; and for a broader survey, see Charles Walton, Policing public opinion in the French Revolution: the culture of calumny and the problem of free speech (Oxford, 2009), pp. 99-123 and $159-92$.

69 ASMi, Atti di Governo, Giustizia Punitiva PM 59, Processo detto di Bologna da riporsi in Archivio, Doc. 5, 3 marzo 1806 , Villa's Report to Guicciardi, fos. 1-4. 
Thus, in the company of these two military policemen, he proceeded to the prefecture. Here, he informed the astounded prefect Teodoro Somenzari that he was ordered by Diego Guicciardi, the director general of police, to confiscate all papers relating to the Oppizzoni affair. Initially, the prefect panicked and claimed to be unable to locate the key to the strongbox containing these papers. $7^{\circ}$ Villa insisted and the files were eventually surrendered into his custody. He then visited Luigi Valdrighi, an eminent jurist who, at this time, was president of the court of appeal of Bologna, and informed him that he was to begin instantly an investigation into the police's activities against the cardinal. ${ }^{71}$ He then took Anna Naldi and her procuress, the elderly Maria Benetti, into custody and transferred them to the more secure prison of Monza near Milan.

Soon after Villa's return to Milan, the prefectural police of Bologna was disbanded and reorganized. The former head of police Giulio Ceregalli and his secretary Andrea Rasinelli were placed under house arrest. $7^{2}$ The prefect was recalled to Milan, where he was to account for his conduct before the viceroy. In the meantime, Valdrighi set about the task of uncovering what the police had been up to over the previous two months. While, on the face of it, it seemed that Ceregalli and his subordinates had merely initiated proceedings against Anna Naldi for libelling the archbishop of the city, soon a more complex and disturbing reality was uncovered. Doctor Gaetano Caneti, a disbarred and rather shady lawyer, had acted as notary during the interrogations undertaken by the police. He was immediately arrested and bullied into a confession.

After some weeks in prison, and fearing for his future, he made some startling revelations. He alleged that the papers confiscated from the prefect represented only a fraction of the depositions actually recorded. He affirmed that he had personally witnessed Rasinelli burning the greater part of the official records in order to cover his tracks. 73 It was alleged that pressure had been put on the witnesses to identify the cardinal and that witness statements had been deliberately modified so that they corroborated Naldi's accusations. To president Valdrighi's increasing concern, a conspiracy seemed to emerge in which the prefect had instructed, or at least turned a blind eye to, his police's inept attempts to ensnare the cardinal in a sexual scandal. The local constabulary seemed to be guilty, at the least, of having abused their authority, if not of criminal conspiracy. 74

Equally worrying for Valdrighi was the growing evidence that the friends and family of the officers in question were putting pressure on the witnesses not to

$7^{\circ}$ Ibid.

71 Ibid.

$7^{2}$ Ibid., Doc. 7, 3 mai 1806 , Guicciardi to Luosi.

73 Ibid., No. $3^{8}$, 'Rapporto concernente tutte le indagini fatte e deposizioni assunte dalla direzione di Polizia generale per mettere nella possibile maggior luce l'affare che motivò il riclamo del Sig Cardinale Oppizzoni.'

74 Ibid., No. 38 , parte II and III. 
give evidence against their kin. For the government in Milan, it became necessary for proceedings to be transferred to more neutral ground. Within days, the papers of the trial and the former police of Bologna were heading in the direction of the state prisons in Milan. A very alarming situation was arising, which had the potential of bringing into disrepute the law enforcement system in the Italian kingdom. Those who had pursued Oppizzoni found themselves the victims of their unsolicited zeal.

The other protagonist of this affair was the prefect Teodoro Somenzari. 75 Unlike Oppizzoni, he had been among the most zealous supporters of the French invasion during the late 1790 os and a prominent Italian Jacobin. Although of Mantuan birth, he had left his native city and joined forces with the radicals of Bologna. Indeed, he was a friend and client of none other than the prominent Bolognese radical Antonio Aldini, who in 1805 had been appointed secretary of state for the kingdom of Italy. $7^{6}$ Somenzari was a competent administrator, who quickly rose through the ranks. Having said this, his ascent had been interrupted briefly in 1800 when he became an Austrian prisoner during the brief Habsburg re-conquest of northern Italy. 77 He spent at least six months in the decidedly unpleasant Austro-Croatian fortress of Bocche di Cataro (present-day Boka Kotorska in Croatia). One can speculate reasonably that during his detention his hatred of the ancien régime aristocracy and religious establishment sharpened.

In many ways, the future Somenzari-Oppizzoni rivalry mirrored (or was a more intense and localized version of) the Aldini-Melzi split which had blighted the summit of the northern Italian satellite state. $7^{8}$ All these men, on the surface at least, collaborated with the French empire, but they did so for vastly different reasons. The 'ancien régime heritage' and 'reluctance' of Melzi-Oppizzoni bore little similarity to the more ideological 'republican-liberal apprenticeship' and 'mistranslations' of Somenzari-Aldini. Milanese aristocrats sought to promote civil order and administrative rationalization. Former Jacobin Bolognese togati wished to improve the lot of their native town and gain power at the expense of the old nobility. The biggest 'mistranslation' between ruler and ruled surrounded the objective of mobilizing different types of Italians to work in partnership for the benefit of the empire. This policy, known as amalgam, sought to fuse collaborators into a new working composite elite. Even in Metropolitan France, these attempts to forge masses of granite delivered decidedly mixed results. The conflict in Rouen between Cardinal Étienne Hubert de Cambacérès and Jacques Claude Beugnot, the prefect of Seine Inférieure, in many ways (excluding the sexual element) mirrored the

75 Antonelli, I prefetti dell'Italia napoleonica, pp. $94^{-6}$ and $145^{-5}$.

${ }^{6}$ Livio Antonelli, 'Antonio Aldini e la segreteria di stato a Parigi', in Varni, ed., I 'Giacobini' nelle legazioni, II, pp. 253-72.

77 Emanuele Pagano, Alle origini della Lombardia contemporanea: il governo delle province lombarde durante l'occupazione austro-russa, I 799-I8oo (Milan, 1998).

$7^{8}$ Cf. del Bianco, Francesco Melzi d'Eril, pp. $214^{-} 5^{8}$. 
Somenzari-Oppizzoni divide.79 Former revolutionary politicians and ancien régime clerics found it immensely difficult to establish cordial working relations. Such rifts intensified beyond the Alps, as collaborators sought to manipulate the empire to settle old scores with their traditional social and regional rivals.

On his release from Bocche di Cataro, Somenzari quickly became an executive commissioner, and in 1802 was appointed prefect to the department of the Reno, whose administrative capital was Bologna. He seemed the perfect man for the job, having sufficiently radical credentials to appeal to his old Jacobin friends in Bologna and determined enough to follow through on some substantial budget cuts imposed by Milan. ${ }^{80}$ Despite being a Lombard, he made himself popular by using local men in the administration and fraternizing amiably with his subordinates, who also shared his radical career path from the triennio Giacobino.

Alas, Oppizzoni, his counterpart with red socks, who had arrived at about the same time, did not endear himself to either the city or its prefect. He was the first-non Bolognese archbishop in centuries, and he brought with him Monsignor Pagani and other Milanese collaborators to help him manage the archdiocese. More controversially, his first priority, following government orders, was the reduction of the number of urban parishes from fifty-three to eighteen. ${ }^{81}$ The civic and religious pride of his archdiocese was deeply injured. The cardinal also had a marked dislike, on a personal level, for Somenzari, whom he refused to meet socially. The prefect held monthly receptions and banquets, which were well attended by the elites of Bologna. The absence of the cardinal was a far from subtle snub.

This bad blood reached its zenith in December 1805 when two Te Deums were sung: one to celebrate the victory at Austerlitz and the other peace with Austria. In the first instance, the cardinal waited till the prefect was absent from the city to hold this solemn ceremony. Thus, effectively he erased his rival from the symbolic hierarchy of the city. Second time round, he could not pull the same trick, but he had another up his sleeve. It had been usual for the city's authorities to have places of honour in the metropolitan cathedral for major religious festivities. Somenzari arrived for the second Te Deum to find that no arrangements had been made to receive him and his prefectural staff. Only the French officers of the city's garrison had had spaces reserved. ${ }^{82}$ Intense dislike sharpened into searing hatred. It seems too much of a coincidence that a few weeks later Anna Naldi came up with her story. Equally

79 Gavin Daly, Inside Napoleonic France: state and society in Rouen, I80o-I8I5 (Aldershot, 2001), pp. 83-6 and 100-4; and Étienne DeJean, Un préfet du consulat: Jacques-Claude Beugnot (Paris, 1907 ), pp. $34^{1-76 .}$

8o Pagano, Enti locali e stato in Italia sotto Napoleone, pp. 66-103.

81 Varni, Bologna napoleonica, pp. 195-7.

82 ASMi, Atti di Governo, Giustizia Punitiva PM 59, Processo Contro gli Agenti di Polizia di Bologna, Doc. 1, 25 maggio 18o6, Witness statement Vincenzo Zabelli and Carlo Bettoni, 26 maggio 1806, Witness statement Canonico Giovanni Lucio Savioli. 
bizarre was the fact that the socks of Oppizzoni's predecessor, Cardinal Boncompagni, literally vanished from a second-hand clothes vendor around the same time. ${ }^{8}$ The judges involved in the case wondered whether these had been stolen by an individual linked to the prefect, in order to impersonate and compromise Oppizzoni.

In all of this, one cannot help but feel a certain admiration for Anna Naldi. Her story of clerical abuse was to cause a furore in Milan, Paris, and Rome. Her tale resurrected the municipal rivalries between Milan and Bologna, the hatred of former Jacobins against privileged noblemen. It pitted the state against the church; equally, it made the position of Italy's French imperial masters very, very uncomfortable indeed. This was something of an achievement for a teenage girl disowned and abandoned by her family for having started an unsuitable relationship with a papal sbirro in her youth. ${ }^{84}$ Was she a clever liar who escaped harsh jail conditions by telling a lie that allowed the prefect of the city to start a campaign aimed at besmirching his ecclesiastical rival's reputation? Or was she the pawn of larger conspiracy, on the part of Bologna's secular elites seeking to rid themselves of a troublesome priest? We will never know the precise answer but her allegations of sexual misconduct certainly made the relationship between the empire and its collaborators tense for much of 1806 .

By March, Napoleon and his administrators realized that they were being forced to make a choice they had desperately hoped to avoid. Should they support a collaborative prince of the church or a loyal functionary? The situation gained urgency as international circumstances took a decidedly unwelcome turn. Papal neutrality during the previous military campaign against Austria had antagonized Napoleon and he was on the verge of violating the sovereignty of Rome. ${ }^{85}$ His troops were soon to march across the patrimony of St Peter and were to occupy the port of Ancona, one of the most strategic locations on the Adriatic. Diplomatic relations between Rome and the empire moved from diffident collaboration to outright hostility. ${ }^{86}$ The growing hostility between church and state during the Napoleonic period, defined as the 'politics of religion', has been treated in great depth elsewhere. ${ }^{87}$

Suffice it to say that the emperor could not afford to lose the few friends he had among the Catholic hierarchy. Equally, his power among the civil service in

\footnotetext{
83 Ibid., 24 maggio 1806 , Witness statement Teresa Franceschelli, owner of bottega nella via Malcontenti.

84 Ibid., Witness statement Antonia Bassi Tognina, prostitute colleague of Naldi.

85 E. E. Hales, The emperor and the pope (New York, NY, 1961), pp. $74^{-85}$.

${ }^{86}$ For the classic narrative, see Joseph Othenin Bernard de Cléron $\mathrm{C}^{\text {mte }}$ d'Haussonvile, L'Église romaine et le premier empire, I 80o-I 8 I4 (5 vols., Paris, 1868-70), II, chs. XXII-XXVII.

87 Jacques-Olivier Boudon, Napoléon et les cultes (Paris, 2002), pp. 245-59; and Michael Broers, The politics of religion in Napoleon Italy: the war against God, I80I-I8I4 (London, 2002), passim.
} 
northern Italy relied on competent and committed public servants, like Somenzari. Much later in this affair he wrote to Eugène in the following terms:

My Son, treat well the patriots of Bologna and those whom you call the partisans of Somenzari...In the gravest circumstances, the patriot party is the one which has always shown itself to be most energetic in its support for France and the throne. Public esteem is an empty word; listening to both parties [in this affair], shows how fickle it can be. Place yourself above petty prejudices and small mindedness. ${ }^{88}$

This was a roundabout way of saying that ultimately an exit strategy needed to be found. By the second half of the year, matters were not helped by the fact that the trial against the police of Bologna was producing unexpected results. The praetor (chief prosecutor) of Milan informed the government that in his opinion the conviction of the four people in the dock - Anna Naldi, her procuress, the chief of police and his secretary - was unlikely. His assessment proved prophetic. The magistrates of Milan's appeal court declared on 30 December 1806 that to their mind no abuses, short of errors of judgement, had been committed by the police and that any conviction for libel was unsafe without an injured party. Therefore, all involved in the trial were acquitted. Oppizzoni's only consolation was to be found in the president of the court's final remark that 'it seems safe to conclude that it is morally impossible that the author of the allegations in question was Cardinal [Oppizzoni]'. ${ }^{9}$ The attempt to keep all sides of this complicated collaboration network on-board was to alienate many members of this affair.

Somenzari, though innocent of any crime, was still guilty of misjudgement. The government's solution was to transfer him to the new, though decidedly less important, Venetian department of the Passariano (Udine). $9^{\circ}$ Here he had a successful career, which culminated in his ennoblement as a baron of the kingdom of Italy. Having said this, he would never again be appointed to a first division prefecture like those of Milan, Venice, or Bologna. Essentially, this affair transformed him from a stormtrooper of the empire into a professional career-bureaucrat who kept his nose clean. ${ }^{91}$ From the final judgement of Milan's appeal court, it could be concluded that the rule of law had triumphed over arbitrary justice. Alas, the viceroy felt that it would be highly undesirable to leave Anna Naldi and her associate at large. Therefore, using his sovereign powers, he had these two women detained, without legal due process, for a further year until the situation had quietened down.

The denouement of the Oppizzoni affair left a decidedly bitter taste for both the government and its collaborators. The cardinal's reputation had not

${ }^{88}$ Napoléon Bonaparte, Correspondance generale, No. 12608, 30 juillet 1806, vI, p. 665 .

89 ASMi, Atti di Governo, Giustizia Punitiva PM 59, Processo detto di Bologna da riporsi in Archivio, No. 48 [Sentenza] Riservata No. 6919=18=15=43=e 6989, Regno d'Italia Milano 3o Xbre 18o6, Il Tribunale d'Appello del Dipartimento d'Olona.

$9^{\circ}$ Antonelli, I prefetti dell'Italia napoleonica, p. 294.

$9^{1}$ ASMi, Atti di Governo, Uffici e Tribunali Regi 642, Somenzari file. 
received the public vindication he had been promised. Alienated from Napoleon, he became the figurehead of the municipal opposition to French rule in Bologna. $9^{2}$ In 1810 , he refused to attend Napoleon's wedding to Archduchess Marie Louise at Saint-Cloud. According to Umberto Beseghi, Napoleon wanted to have him shot after he had done so much to protect his reputation. Cooler counsels prevailed; Oppizzoni was deprived of his crimson robes and became one of the thirteen opposition 'black cardinals' imprisoned in different fortresses until 1814.93

The imperial government sought desperately to preserve its collaboration networks, in Bologna, in 1806 , but found the path to achieving this objective fraught with difficulties. Napoleon, Eugène, and their ministers showed themselves unsure of how to quench endogamous Italian rivalries and remain aloof from such disputes. It is true that the government put little pressure on the Italian judiciary, but the verdict of acquittal cannot have been very welcome. It highlighted, and made visible, one of the problems Paris found most intractable. Namely, a sense of impotence when it came to dealing with and harnessing cultures of regional collaboration for the benefit of the empire. In the end, an increasingly bewildered Napoleon impotently turned from Ornamentalism to Orientalism in the blink of an eye. In a letter to Eugène, he could only lament: 'Beware of the prattle of Italians. If the prefect of Bologna is guilty he will be punished. Believe me Aldini is too clever to write stupidities. The country in which you find yourself is a land of idle gossip.' 94 The frustration expressed here by Napoleon highlighted how the difficulties of ruling a vast multi-national empire could prove insoluble. Collaboration, no matter how desirable, was shipwrecked easily on the dangerous rocks of individual, competing and conflicting, interests. Governmental, local, municipal, aristocratic, and radical agendas intersected in unpredictable and uncontrollable ways in northern Italy.

The empire tried hard to accommodate the majority of the parties in the Oppizzoni affair. It could be suggested that it worked hardest (perhaps uncharacteristically) in seeking to avoid alienating the ecclesiastical element in this scandal.95 Several times the emperor hinted, with varying degrees of subtlety, towards a cover-up as the only viable solution. ${ }^{6}$ Yet satisfying the expectations, or rather the agendas, of native collaborators proved intractable. The prefect had used (or at the very least encouraged his subordinates to use) the administrative apparatus at his disposal to damage his ancien régime/ecclesiastical/

\footnotetext{
$9^{2}$ Varni, Bologna napoleonica, pp. $25^{6-61 .}$

93 Beseghi, I tredici cardinali, pp. 121-4.

94 Napoléon Bonaparte, Correspondance generale, No. 11896,14 avril 1806 , vI, p. 324 .

95 Broers, The politics of religion, pp. 86-99.

$9^{6}$ Napoléon Bonaparte, Correspondance générale, No. 11788,27 mars 1806, vi, pp. 276-7; and ibid., Nos. 23392 and 23398, Paris, 3 avril 181 o, x, pp. 89-9o and esp. p. 92, "[a prelate] whom I protected and whose sexual shenanigans I covered up by using my authority to interrupt the course of criminal justice in Bologna'.
} 
regional rival. Government expressed deep concern over how the machinery of the empire-state could be subverted by local elites for their own petty personal designs.

The cardinal, for his part, descended on the viceregal court at Milan, like an avenging fury, to defend his reputation and eliminate his prefectural and revolutionary antagonist. This takes us to the heart of the question as both Cardinal Oppizzoni and Prefect Somenzari were collaborators. Yet their engagement with the centre was hardly one of passive ideological commitment. Their collaboration was founded on reluctance and mistranslating the imperial state's mission into more personal and regionalized terms that fitted their own circumstances. They, ultimately, dragged their imperial overlord into a quarrel that was alien to the evolving Napoleonic project. Collaborators were supposed to lubricate nuts and bolts of government; here, instead, they sparked a serious breakdown in local administration.

For months, Bologna remained without its highest officials and bereft of a police force. 97 According to Angelo Varni, crime increased during this interregnum..$^{8}$ The collapse of order was the antithesis of French rule. Regional and pre-Napoleonic identities were not only at the heart of this scandal, but had constantly the potential of upsetting the delicate balances and partnerships created by the empire. In many ways, both the empire and its Italian collaborators picked up the pieces after 1806 . At times of crisis the secular administration, and urban elites, of Bologna renewed their steadfastness to their French masters. The 1809 war against Austria led to a series of atavistic peasant insurrections throughout the satellite kingdom. When a large group of insurgents appeared before the walls of Bologna, the prefecture, municipality, and national guard all solidly stood together to withstand a veritable siege.99 After the collapse of the relations with the papacy, the imperial administration stood firmly with the former 'Giacobini', and clerical collaboration largely evaporated. ${ }^{100}$

The Napoleonic behemoth drastically redrew European borders, institutions, and values. ${ }^{101}$ From 1789 , it had inherited a disdain for tradition and regional diversity. ${ }^{102}$ The men it sought to co-opt in working for the grand imperial design not only had a multiplicity of conflicting ambitions, but, even more importantly, they had divergent pasts. The well-known policies of ralliement and amalgame, which formed the basis of the compact at heart of imperial society,

97 Varni, Bologna napoleonica, p. $25^{6}$.

$9^{8}$ Ibid.

99 G. Natali, 'L'insorgenza del 1809 nel dipartimento del Reno', Atti della regia depitazione di storia per l'Emilia e la Romagna, anno xv, vol. II (1936/7), pp. 43-109; and, more generally, Rinaldo Spadoni, Le Insorgenze contadine in Val Padane nel periodo napoleonico I804-I8I4 (Bologna, 1972), passim.

${ }^{100}$ Boudon, Napoléon et les cultes, pp. 263-76.

${ }^{101}$ Woolf, Napoleon's integration of Europe, pp. 1-32.

${ }^{102}$ Michael Broers, 'The Napoleonic empire', in Alan Forrest and Peter Wilson, eds., The bee and the eagle: Napoleonic France and the end of the Holy Roman Empire, I 806 (Basingstoke, 2009), pp. $65^{-82}$. 
had been born as a specific means of healing the divisions of the revolutionary decade in France. ${ }^{103}$ Only within the metropolis could these policies approach success (and even here they were hardly guaranteed to function). ${ }^{104}$ As Howard G. Brown has stated, 'the ability to combine revolutionary winners and losers in a semi-permanent political elite provided one of the key conditions of stability under Napoleon'. ${ }^{105}$ Former ancien régime and revolutionary elites put the past behind them (temporarily at least) in an attempt to get beyond the factional turmoil and disorders of the 1790 . Having lost so much in the revolutionary maelstrom, French elites had everything to gain by working with a regime founded on the selective oubli of the immediate past.

Beyond the Rhine, Pyrenees, and Alps, the situation was very different. The traumas, divisions, and expectations of the populations conquered by the French had little to do with revolutionary politics but everything to do with local and atavistic forces. Prelates, Jacobins, aristocrats, lawyers, mayors, merchants, and other groups may have played lip service to the rhetoric of amalgame and ralliement but they could not straightforwardly translate these terms to fit their own context in a meaningful manner.

Even in the Napoleonic kingdom of northern and central Italy, one of the success stories of the empire, the programme for creating a new composite collaborative elite ran into significant difficulties. Bolognese collaborators were distrustful of their Milanese counterparts whom Napoleon had unleashed on their city. The promotion of Lombards, during 1 796-1803, to the highest summits of the Italian satellite state was resented. ${ }^{106}$ Municipal loyalties were keenly felt, allegiances toward the new polity were delicate at best. ${ }^{107}$ Amalgame beyond the Alps could act as a social sledge hammer rather than a soldering iron. ${ }^{108}$ Analogies can be found in Livio Antonelli's study of the mixed results elicited by the attempt to appoint Venetian prefects to Lombard and Emilian departments. ${ }^{109}$ Unlike their French masters, for whom the traumas of the 1790 os had bred a desire to let bygones be bygones, northern Italians had long memories of distrust for each other, which could not be erased in a short space of time. The imperial overlords, rather than settling such disputes, found themselves drawn by its collaborators into frightening vortices of localism. The centrifugal forces of locality, municipality, and campanilismo had an iron grip on this

\footnotetext{
103 Michael Broers, 'The first Napoleonic regime, 1799-1815: the origins of the positivist right or the zenith of Jacobinism?', in Nicholas Atkin and Frank Tallett, eds., The right in France from I 789 to 1997 (London, 1997), pp. 19-34.

104 Broers, The Napoleonic empire in Italy, I796-18I4, pp. 175-212.

${ }^{0} 5$ Howard Brown and Judith A. Miller, eds., Taking liberties: problems of a new order from the French Revolution to Napoleon (Manchester, 2002), p. 29.

106 Varni, Bologna napoleonica, pp. $65^{-7} 1$ and 197.

${ }^{107}$ Roberti, Milano capitale napoleonica, I, pp. 4, 21-3.

108 Broers, The Napoleonic empire in Italy, I 796-I8I4, pp. 175-212.

109 Antonelli, I prefetti dell'Italia napoleonica, pp. 278-99.
} 
corner of Italy, but one suspects that elsewhere in the empire much the same thing was afoot.

The elites of Bologna were among the most devoted of Napoleon's Italian subjects. They often received positive mentions in dispatches and were commended for their service. They patiently waited and hoped that their new governors would reward them with power, prestige, and most importantly autonomy. In 1804, the grip on political power held by the Milanese began to loosen when Melzi d'Eril was sidelined. ${ }^{110}$ The creation of the kingdom of Italy gave the Bolognese some indications that the pendulum was swinging in their favour. They scanned the sky for other encouraging omens and found them. ${ }^{111}$ The new royal regime seemed to bring the greatest of all intoxicants: possibility.

With unparalleled clumsiness, in 1806 the prefect of the city, the local administration, the police, and even Aldini in Paris tried to pounce on their unwelcome Milanese cardinal. One could speculate that they hoped that the empire would bow to localistic rivalries. Instead, Napoleon and Eugène received a terrifying lesson in the precariousness of collaboration networks and the dangers of being reluctantly drawn into local politics. This case may be exceptional in the extent to which the prefect and his Bolognese supporters were prepared to go to rid themselves of Oppizzoni but it exemplifies well the difficulties of harnessing local support outside of the Metropole. Everywhere in Europe, collaboration proved a double-edged sword. It was a necessary instrument for governance but one that could be used by locals to redirect the empire's agenda.

110 Zaghi, L'Italia di Napoleone, pp. 49-52.

111 Antonino de Francesco, L'Italia di Bonaparte: politica, statualità, e nazione nella penisola tra due rivoluzioni, I796-I82I (Turin, 2011), pp. 77-81. 